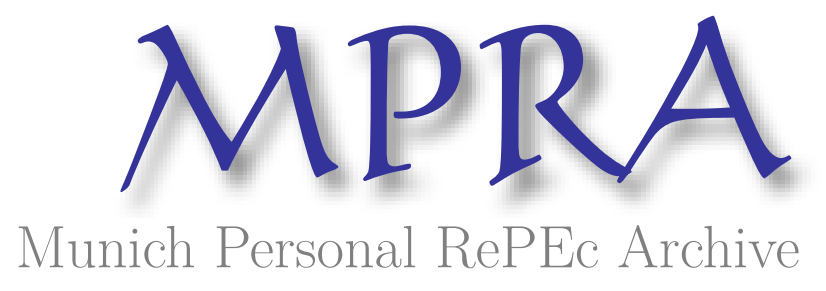

\title{
Cost, Uncertainties and Profit in Commercial and Social Insurances
}

Nizam, Ahmed Mehedi

29 June 2021

Online at https://mpra.ub.uni-muenchen.de/108523/

MPRA Paper No. 108523, posted 04 Jul 2021 14:30 UTC 


\title{
Cost, Uncertainties and Profit in Commercial and Social Insurances
}

\author{
Ahmed Mehedi Nizam \\ The Central Bank of Bangladesh \\ ahmed.mehedi@bb.org.bd \\ ahmed.mehedi.nizam@gmail.com
}

*Publisher version of the paper is available at: https://link.springer.com/article/ $10.1007 / \mathrm{s} 43546-021-00097-\mathrm{y}$

\begin{abstract}
Here, we argue that the commercial for-profit insurance companies act more like a memory-less system in a way that the premiums paid by the policy holders during one accounting period will be of no avail to them during subsequent periods although the excess premiums earned in the previous periods may rest in the companies' retained earnings. Moreover, commercial insurances are subject to many over-head costs, taxations and uncertainties which are not present in the realm of social insurances. As the costs and uncertainties are greatly reduced and the profits earned in the previous periods are available to meet present and future expenditures, social insurances entail a lower amount of premium for the policy holders than its conventional commercial counterpart. The objective of this study is to quantify the extent of profit made by the commercial insurance companies born out of the premium after meeting up operating expenditures and claim settlements and how this profit evolves over time after being invested at the risk free rate. To us, this is the amount of money that would otherwise rest in a trust fund available for future claim settlement if there were equivalent social insurance schemes in place. To do so, we collect annual country level data of premium collection, claim settlement and operating expenditure incurred for 04 (four) OECD countries from OECD insurance database [28] and extrapolate the profit trends into the future using appropriate ARIMA/ARIMA-GARCH framework. As anticipated, the profit shows an explicit upward trend after making a $V$-shaped recovery right after the global financial crisis of 2008 .
\end{abstract}




\section{Keywords}

Social insurance; Commercial insurance; Comparative analysis; ARIMA-GARCH modeling

\section{Introduction}

Concepts of social insurances have been heavily used throughout the developed 2 world to implement universal health coverage, unemployment insurance, illness and 3 disability insurance scheme and various other social safety net programs. Although, 4 such programs across the world may vary in terms of coverage and contribution 5 from the individual, they have some common traits: All such programs are state- 6 sponsored and are implemented as not-for-profit trust funds instead of for-profit 7 limited liability companies. The contributions to the scheme are often mandatory 8 or heavily subsidized that lures the eligible candidates to willfully sign up for the 9 scheme. Thus extensive risk pooling is carried out in the process and if there is any 10 shortage in the raised fund then it will be compensated from the general taxation ${ }_{11}$ revenue. Examples of such schemes include but not limited to Medicare [14], Pension 12 Benefit Guaranty Corporation program [10], the Railroad Retirement Board program ${ }_{13}$ [41] in United States, Canada Pension Plan (CPP) [23], German Sickness fund and ${ }_{14}$ unemployment insurance program [18], Italian National Health Services program 15 [40] and so on. Scope of the social insurance is thus far largely limited to the social 16 security programs and they have never been tried for in other commercial setup like ${ }_{17}$ fire and allied insurance, industrial all risk insurance, burglary and housebreaking, 18 marine cargo insurance, cash in transit, cash in safe, cash on counter insurance, 19 fidelity guarantee insurance, motor car and house insurance and many others. Here, 20 we argue that the commercial for-profit insurance companies for the above-stated 21 purposes collect substantially more premiums than the consolidated amount of claim 22 settlements and incurring operating expenditures. Thus they have surplus in their ${ }_{23}$ premium collection account and from this, they make payment for corporate and 24 premium taxes, pay their agents for marketing purposes, reward their owners through $\quad 25$ dividends, spend money for advertising and publicity purposes and frequently indulge 26 in risky investments and often incur losses in the process. Social insurance scheme ${ }_{27}$ does not have any of the stated over-head costs except for claim settlement and ${ }_{28}$ meeting up operating expenditures. So, if all the stated insurance schemes would have 29 been implemented as state sponsored not-for-profit social insurance scheme, then the 30 amount of extra premiums collected on the process would rest in the trust account ${ }_{31}$ instead of being spent on different over-head costs as mentioned above and would 32 
be available for future claim settlement. This would heavily reduce the premium 33 burdens on the policy holders in the periods to come. The policy holders would 34 still get the same amount of coverage in terms of claims, operating expenditures 35 would still be met sustainably from the internal sources (from the premiums) and 36 no subsidy from the government side would have been required. 37

Here, we argue that the social insurance program can provide more affordable 38 means of risk mitigation than the commercial insurances. If the profit of the insurance 39 company is retained instead of being distributed to the stockholders and if we can 40 escape the agency commission and advertising expenditure by making the subcription $\quad 41$ to the scheme mandatory and eliminate corporate and premium taxes by incorporating 42 it as a not-for-profit trust fund then a substantial amount of future claims can 43 be settled from the previously earned premiums and accumulated interest there 44 on. Here, we try to quantify the excess premiums paid by the policy holders 45 over the course of time with up to date accrued interest and analyze its trend 46 using the empirical data of 04 (four) OECD countries. The rest of the article ${ }_{47}$ is organized as follows. Section: 2 sketches a brief overview of the birth of the 48 commercial and social insurances and how they evolve to their current forms over 49 the course of time. Section: 3 provides the formal definition of social insurance. In 50 section: 4, we describe different cost heads which are exclusively associated with 51 commercial for-profit insurances. Section: 5 discusses several risk factors inherent 52 to the commercial insurance scheme which are not applicable for a government- ${ }_{53}$ run not-for-profit social insurance scheme. Section: 6 explains the methodology 54 followed to quantify the overhead costs associated with the commercial insurances. $\quad 55$ Section: 7 presents the methods used to forecast accumulated profit gathered by 56 different commercial insurance companies in 04 (four) OECD countries. Section: 857 tabulates the forecasting results. Section: 9 analyzes the findings from a country- 58 level perspective. Section: 10 presents the limitations and future scope of the current $\quad 59$ study and finally, Section: 11 concludes the article.

\section{Birth and Evolution of the Commercial and Social ${ }_{61}$ Insurance

Concept of insurance as a risk management technique dates back to the early Bronze $\quad 63$ Age (4th Millennium BC) when the Babylonian traders widely used the so called 64 bottomry contract as a tool to mitigate maritime risk [11]. In bottomry contract, 65 loans were given to the seafaring merchants by taking the ship and the cargo within 66 it as security and loans would only be repaid with handsome interest if the ship 67 
returned after a successful voyage. If instead, the ship capsized into the sea in the 68 middle of a voyage then loans were waived off. The concept survived as only a 69 handful of ships experienced the perils of the sea while the rests were successful 70 in their voyage and paid back the loan with opulent interest. Thus the concept of ${ }_{71}$ risk sharing took its first route through human society in a marine pathway and 72 underwent a dramatic set of evolution ever since. Chinese traders of the early to ${ }_{73}$ middle Bronze Age (3rd millennium BC) adopted a new approach to risk mitigation 74 and used to redistribute their maritime damages across all participating vessels in 75 order to keep the losses to a reasonable proportion for each sailor in the sea [39]. 76 Similar techniques had been applied by the Babylonians in as early as middle to 77 late Bronze age (2nd millennium BC) and was inscribed along with other 281 laws 78 into the famous Code of Hammurabi by the 6th Babylonian king Hammurabi. The 79 maritime law of general average was invented and practiced by the Rhodians during 80 the Iron Age (1st millennium BC) where all the stakeholders proportionately shared 81 the total maritime losses. Rhodes, being a small, seafaring nation of southern europe, 82 established trading colonies along the costs of Italy, France and Spain. As venturing 83 through the seas became their main course of business they developed the first set 84 of ancient maritime laws of dispute settlement and documented it in Lex Rhodia 85 which is popularly known as the ancestor of all maritime laws [15]. Lex Rhodia, as 86 a set of maritime laws, had been eventually adopted by the Roman empire into its 87 constitution as can be seen from the Digest of Justinian, Book XIV, Title II compiled 88 by the order of Eastern Roman emperor of the 6th century Justinian-I [9].

Meanwhile, the concept of group insurance tended to evolve in the ancient Roman $\quad 90$ empire when merchants and craftsmen formed associations/guilds of their own for 91 mutual benefits and for the furtherance of their professional interest. Guilds formed 92 in the Roman era eventually fell with the Roman empire [12] and the practice was 93 invigorated again in the medieval Europe. Confraternities of craftsmen including 94 masons, carpenters, carvers were formed in Europe during the middle ages [21] 95 which served the common interest of the craftsmen, gave them substantial bargaining 96 power, protected them from catastrophe and stored wealth in the coffers which acted 97 as a cushion against risk.

However, the first specimen of insurance as a separate contract was drafted in 99 Genoa, Italy on Februray 13, 1343 which marked the break from the ancient practice 100 of Mutuum Nauticum or marine loan which was proved to be inadequate to meet the 101 needs of a sedentary merchant during the commercial revolution [27]. The great fire 102 of London in 1666 which destroyed nearly 13,200 houses accelerated the development 103 of modern fire insurance and the first company of its kind to offer fire insurance for 104 the properties came into existence in 1681 under the name 'Insurance Office for ${ }_{105}$ 
Houses'. The development of modern marine insurance is tied to Edward Lloyd, a 106 Welshman who opened a coffee house in Tower Street, London. Lloyd's coffee house ${ }_{107}$ in Tower Street became a vibrant meeting place for sailors, traders and underwriters 108 which, after a successful metamorphosis, turned into Lloyd's of London [31], [26], 109 London's premier insurance and reinsurance market. The first company to offer life 110 insurance was formed in London in 1706 by William Talbot and Sir Thomas Allen 111 [5], [17].

Thus far, insurance companies formed in Europe during the enlightenment era 113 were privately incorporated with no government involvement. However, as the 114 concept of welfare state evolved in Europe during the late nineteenth century, governments began to take part in insurance market with a view to ensure economic and social 116 welfare of its citizens. It was the conservative German chancellor, Otto Von Bismarck 117 who took the first attempt to promote healthcare for the underprevileged through 118 Sickness Insurance Law of 1883. The bill was intended to protect the German ${ }_{119}$ industrial workers from various health hazards by drawing periodic contribution 120 from both the employers and the employees. The bill was the first one in a row ${ }_{121}$ which was followed by Accident Insurance Law of 1884 and Old Age and Disability 122 Insurance Law of 1889. The waves of welfare oriented thinking in Germany crossed ${ }_{123}$ national boarder and reached the mind of the British politicians which resulted into 124 passage the The National Insurance Act 1911 in the parliament which provided 125 the British workers and their dependents the first contributory system of insurance 126 against illness and unemployment [19]. Government funded insurance program or the 127 social insurance became a common sight in the healthcare sector of twenteith century 128 Europe and universal health care system has been implemented in many European ${ }_{129}$ countries including Sweden (1955)[33], Iceland (1956)[22], Norway (1956)[13], Denmark 130 (1961)[16], Finland (1964)[4] and the list continues to grow. So far, the concept of 131 social insurance has only been heavily used to finance universal health coverage, state- ${ }_{132}$ run unemployment and disability insurance programs and various social security 133 schemes and has never been used to provide commercial insurance products like auto 134 insurance, fire, riot and earthquake insurance, property, marine, overseas insurances 135 and things alike. Here, we explore the possibility of social insurance paradigm to 136 deliver commercial insurance products and perform some sort of what-if analysis on 137 it.

\section{The Social Insurance}

Social insurance system is indeed an insurance scheme that is run and administered 140 by the state itself. When a state attempts to protect its citizens from various 141 
economic and social hazards by risk pooling, a social insurance scheme is born. Social 142 insurance scheme is achieved through compulsory contribution from all citizens of a 143 country to a state-administered trust fund which is then used to fund disability and ${ }_{144}$ old age benefits, medical care and other social security programs [1]. Dissecting the ${ }_{145}$

above definition of social insurance exposes its main characteristics:

146

- Social insurance is a government sponsored insurance program. Benefits, eligibility47 and coverage are often defined by statute.

- Unlike commercial insurance, premiums and claims are attributed to a not- 149 for-profit trust fund. Excess premium received during an accounting period 150 will retain with the fund and any shortage of fund will be addressed by the ${ }_{151}$ government from the general taxation revenue.

- Subscriptions to the scheme are often mandatory in order to compensate for 153 adverse selection and moral hazards.

Social insurance being a government sponsored not-for-profit insurance scheme 155 slashes some major cost heads associated with conventional commercial insurance 156 including agency commission, advertising expenditure, dividend expense, corporate 157 taxes and so on. Moreover, certain uncertainties like probable winding up and 158 bankruptcies of the commercial insurers are eliminated which add to customer satisfactioad and reduction of premium. Reduction in premium is partly due to the fact that 160 uncertainties and probable losses are usually accounted for by building up extra 161 provisions which are sourced from accumulated profits/retained earnings which, in 162 turn, are built up from collecting extra premiums from the policy holders. A brief ${ }_{163}$ description of some costs and uncertainties associated with commercial insurance is 164 presented in the next section.

\section{Overhead Costs Associated with Commercial For- ${ }_{166}$ Profit Insurance Companies

Certain cost heads associated with modern commercial insurances simply do not 168 exist in the realm of social insurances. A yet not comprehensive list of some of these ${ }_{169}$ staggering expenditures involved only with the day to day management of a for-profit 170 commercial insurance company is appended below.

171

- Agency commission: Private for-profit insurance companies often recruit licensed 172 agents to sell their products to people. The compensation of the agents depends ${ }_{173}$ 
upon the companies' commission policy as well as on the number of policies sold 174 by the agents. Higher the number of policies sold by the agents higher will be their 175 compensation. For term life insurance, agents may make up to 40-90\% of the first 176 year premium of the policies they sold and $2-5 \%$ or less in the subsequent years [24], 177 [37]. According to the data provided by US Bureau of Labor Statistics, the median 178 pay for an agent is $\$ 50,560$ per year or $\$ 24.33$ per hour as on 2018 [38]. Moreover, 179 OECD insurance statistics suggest that total commission expenditure for direct 180 insurance in US alone amounts to nearly $\$ 140.97$ billion during 2018 (Commission 181 expenditure for direct life and non-life insurance amount to $\$ 51.21$ and $\$ 89.76{ }_{182}$ billion respectively [29], [30]). An infographic of US commission expenditure for ${ }_{183}$ direct insurance during 2008-2018 is presented in Fig: 1. Data presented in Fig: ${ }_{184}$ 1 are collected from 'Balance sheet and income series' for direct life and non-life 185 insurance companies in United States from OECD insurance database [29], [30]. 186 These huge expenditures are met up from the premiums collected which eventually $\quad 187$ results into a higher premium burden on the policy holders.

Figure 1: Commission for direct insurance in US

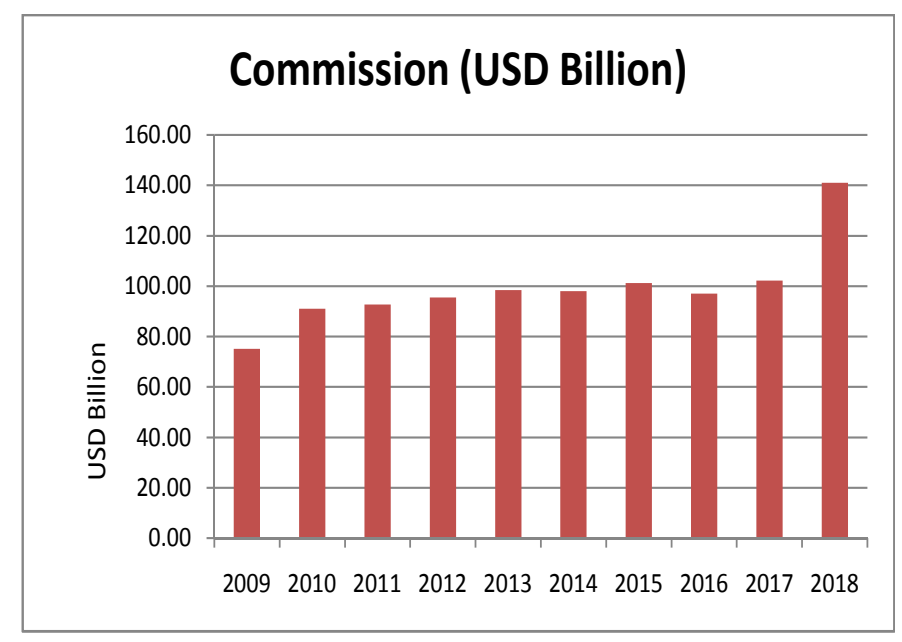

On the other hand, for social insurance, there is no agency commission as every 189 eligible candidate is mandated by law to participate in the scheme. As agency 190 commissions are simply wiped out social insurances are supposed to entail lower 191 insurance premium as compared to their commercial peers.

- Advertisement and publicity cost: Private insurance companies like all other 193 for-profit limited liability companies tend to spend an extensive amount of money ${ }_{194}$ on advertising which includes but not limited to print and online platforms advertising,95 
radio and television broadcasting, email marketing etcetera. According to $\mathrm{S} \& \mathrm{P}{ }_{196}$ Global Market Intelligence [34] top 04 (four) US auto insurance underwriters 197 jointly spent $\$ 4.01$ billion on advertisement during 2017. Not to mention this 198 staggering expenditure is made through the profits of the insurance companies 199 which is mostly accumulated through the collection of premiums. Social insurance 200 happens to avoid such an overwhelming cost as there is no incentive to advertise: 201 Every eligible candidate is mandated to sign up for the scheme by statute. 202

- Payment of dividends: Like all other for-profit companies private insurance 203 companies are collectively owned by their share holders and are liable to their 204 boards of directors for the payment of a handsome amount of dividend on an 205 annual basis. According to the latest data available to date (2020), yearly dividend 206 yields for top 10 (ten) life insurance companies in US range from $14.27 \%$ to $4.04 \% \quad 207$ which are well above the risk free rate [8]. Total industry average of life insurance 208 dividend yield is found to be $4.05 \%$ which is greater than the weighted average 209 bank deposit rate of the US [8]. As these dividend yields are mainly derived from 210 the receipt of the premium from the policy holders they add substantially to the ${ }_{211}$ premium and are supposed to provide an upward thrust on to it. On the other ${ }_{212}$ hand, as the social insurance programs are usually sponsored by the government 213 and are usually implemented as not-for-profit trust funds they do not come up with ${ }_{214}$ yearly dividend yields for their owners which interprets to a significant reduction 215 in premium.

- Dividend equalization: In order to streamline dividend payments through busines\$17 cycles many for-profit companies often choose to build up dividend equalization 218 accounts which are entirely sourced from the profit during economic booms. Profit 219 stored in the dividend equalization account during economic boom is used to 220 distribute a healthy proportion of dividends to the share holders even during 221 economic downturn when annual profits are relatively scarce. Dividend equalization 222 account thus created will mean nothing to the policy holders who purchase insurance 223 policies and is intended for the benefits of the stock holders of the insurance ${ }_{224}$ companies at the expense of the policy holders.

- Tax payments: Insurance companies are subject to different kinds of taxes and 226 types and extents of these taxes depend upon the jurisdiction in which they 227 are incorporated and operating. Generally, two broad categories of taxes are 228 imposed on the insurance companies: taxes on premiums and taxes on corporate ${ }_{229}$ profit. Taxes on premiums are usually collected on gross premiums received by the 230 insurance companies in an accounting year and in US the tax rates usually vary ${ }_{231}$ 
across the states. For example, average health insurance tax on premium is found 232 to be $2.25 \%$ of the premiums and it ranges from as high as $4.625 \%$ in Hawaii to as 233 low as $0.0 \%$ in Utah [2]. At the same time like all other for-profit companies the ${ }_{234}$ insurance companies are also subject to corporate taxes which are calculated on its 235 total taxable income in one accounting year. In this case effective tax rate can be 236 as high as $30 \%$ for the health insurance companies incorporated and operating in 237 US [2]. In addition to the above two types of taxes, insurance companies are also 238 supposed to pay retaliatory taxes which are intended to equalize assessed taxes 239 on foreign and domestic insurers operating in a particular state in US. On the 240 other hand, surpluses of the social insurance scheme like the surpluses of all other ${ }_{241}$ not-for-profit organizations as well as the premiums they collect are tax-exempt. $\quad 242$

- Non-Retention of Profit: In the previous sections we have discussed different 243 cost heads associated with the commercial for-profit insurance companies including $\quad 244$ agency commission, dividend expenditure, dividend equalization, advertising and 245 publicity expenditure and tax expenditure whereas social insurances being not-for- 246 profit government regulated schemes are carefully shielded away from all such costs. 247 Moreover, any earning that are retained with the commercial insurance companies 248 after meeting up all the costs only adds to the capital base of the companies 249 which eventually enhances the shareholders' equity with no perceived impact with 250 the premiums imposed upon the policy holders. In other words excess premiums 251 collected in an accounting year by the commercial for-profit insurance companies 252 will be of no use towards the determination of the premiums in the upcoming years. $\quad 253$ On the other hand in social insurance all incomes and expenditures are usually 254 reflected to the balance of a trust fund [1] and any excess in this account is available 255 for future claim settlement and meeting up upcoming operating expenditures which 256 supposedly reduces the premium burdens on the policy holders in the periods to 257 come.

\section{Risk Factors Associated with the For-Profit Commercial Insurances

As the commercial insurance companies are usually privately incorporated for- 261 profit companies they are subject to several profit maximizing ill-practices and 262 volatilities. The following paragraphs are intended to name a few of such uncertainties63 inherent to commercial insurances.

264 
- Bankruptcy after making risky investments: Insurance companies often 265 indulge into risky businesses with a view to make an exorbitant profit. While the 266 profits from these risky ventures (if any) are distributed amongst the share holders 267 as dividends the losses arising from these are usually born to the policy holders 268 through enhanced premiums. In some cases, the losses arising from these risky ${ }_{269}$ investments are so magnanimous as to lead the insurance company itself to the 270 brink of bankruptcy. The near failure of American International Group (AIG) back ${ }_{271}$ in 2008 which was then a leading multinational finance and insurance company 272 with over $\$ 1.0$ trillion in assets is a classic example of the indulgence of insurance 273 companies with risky assets. It is estimated that during 2008 financial crisis, AIG 274 lost nearly $\$ 99.3$ billion which was then rescued by Federal Reserve Board, the 275 Federal Reserve Bank of New York and the US Treasury and the rescue package ${ }_{276}$ amounted to nearly $\$ 182.3$ billion [25]. It is said that AIG invested heavily in 277 mortgage backed securities resulting to a loss of $\$ 21$ billion. Another $\$ 28.6$ billion 278 losses stemmed from the credit default swap that had been written down by AIG 279 [25]. In the absence of $\$ 182.3$ billion rescue package AIG would be forced to file 280 bankruptcy which would create uncertainties for its policy holders. Near failure of 281 AIG is not the only time in history when an insurance company attempts to file a 282 bankruptcy after losing its fortune in risky ventures. In fact, it is very prevalent 283 and the bankruptcy of Executive Life Insurance Company after investing heavily 284 in junk bonds is another notable example in this regard. During the junk bond 285 market turmoil of 1989-1990 the company attempted to write down nearly $\$ 515 \quad 286$ million of its junk bond portfolio which exacerbated its eventual failure, cut public 287 confidence and brought about regulatory intervention [7]. On the other hand, 288 social insurance being sponsored by the government itself and run on sovereign 289 guarantee is quite immune from the possible bankruptcies as it does not usually 290 involve itself in the risky game of profit making through unsafe and highly volatile 291 investments.

- Vulnerability to negative publicity: Private insurance companies are very 293 much vulnerable to adverse publicities both in online and print media. Sometimes 294 the intensity of negative publicity may be so acute as to contribute heavily to 295 the ultimate winding up of an insurance company. One classic example when 296 bad investments coupled with negative publicity added to the eventual collapse 297 of a life insurance company is the case of Executive Life Insurance Company 298 which was a main subsidiary of First Executive Corporation back in 1990s. In 299 January 1990 amidst the junk bond market turmoil, First Executive Corporation 300 (FEC) attempted to write down some $\$ 515$ million of its junk bond exposures 301 
which resulted into an immediate rating downgrade and regulatory restrictions 302 on FEC. Critical media coverage of FEC writing down its junk bond investments 303 and the subsequent regulatory measures hastened FEC to the liquidation of some 304 additional $\$ 4.0$ billion assets in junk bond market (the point when the junk 305 bond market reached its bottom) and this collapse was partly due to the adverse 306 publicities faced by FEC [7]. Although, competitors of FEC in the life insurance 307 market faced even worse downturn as their real estate portfolio underwent a 308 $36.6 \%-41.6 \%$ decline as compared to the junk bond market decline of only $9.2 \%$. 309 While the competitors survived, FEC collapsed mainly due to adverse publicity 310 campaign which discriminatively targeted FEC [7]. On the other hand, as the 311 social insurances are not profit oriented, do not invest in risky securities and are 312 usually backed by government guarantee they are actually immune from these 313 negative propagandas and to date no such incidence in the social insurance arena 314 is recorded. 315

- Window dressing and payments of inflated tax on profit: Window dressing 316 is an umbrella term and generally encompasses a diverse set of accounting tactics 317 generally practiced by many for-profit organizations which is intended to make 318 its annual financial statements look promising to its investors as well as creditors. 319 With a view to creating a positive impression amongst its stakeholders many for- 320 profit companies often show an artificially inflated profit in its financials. On the 321 way, it eventually compels itself to pay higher corporate taxes on the profit it never 322 realizes in true sense with the sole benefit of showing a better financial health than 323 actual. There are a plenty of techniques of window dressing. To name a few, a 324 company may choose to capitalize its current expenditures to enhance its apparent 325 profitability in the eyes of potential investors. If the expenses would be accurately 326 booked into the account then the company's profitability would have been quite 327 low and in fact that would be the true profit of the company. As the company's 328 profit is subject to corporate taxes at a very high rate, in doing so, the company 329 chooses to be taxed on the profit it never earns. This acts as a vicious cycle which 330 reduces the profitability of the company in the subsequent periods which lures the 331 company to window dress even more in near future. In fact, this has been one of 332 causes of the bankruptcy of WorldCom back in 2002 which was then the world's $3 з 3$ largest bankruptcy filing in history [3]. It is said that the WorldCom's problem 334 was partly due to the fact that it heavily capitalized its current expenditure only to 335 show an artificially high profit in its financials i.e., profits were overstated by $\$ 3.8336$ billion [3]. Like all other for-profit companies the whole bunch of window dressing 337 techniques are there in the disposal of the privately held insurance companies which 338 
may be enticed to adopt any of these fraudulent techniques hampering the greater 339 interest of the company and policy holders in the long run. Although scams in 340 the level of WorldCom are yet to be identified in the insurance sector, financially ${ }_{341}$ distressed insurance companies are found to be more prone to window dressing than 342 their solvent counter parties during 1970s [32]. Specifically, when the insurance 343 regulators opt to use financial ratios as benchmarks for overall financial health of 344 the insurance sector they need to be aware of possible window dressing and should 345 update their models every now and then [32]. In more recent times numerous other 346 studies have reported the problem of probable window dressing by the insurance 347 companies and have suggested regular update of regulatory framework to tackle 348 down the issue (See for example, Chen and Wong (2004) [6], Sikes et al (2014) [35] 349 among others). On the contrary, social insurance being a government sponsored 350 program does not happen to have a profit-craving management and board which 351 may choose to hamper the greater interest of the company itself as well as the 352 policy holders by hiding its true financial picture.

\section{Quantifying the Overhead Cost Associated with ${ }_{354}$ Commercial Insurance

In the previous sections we have discussed different cost heads that are exclusively 356 related to commercial insurance and are not found in the realm of social insurance. 357 For example, the commercial insurances are supposed to pay agency commissions to 358 their agents, distribute a handsome proportion of their annual earning as dividends 359 to their owners, invest extensively for promotional purposes and so on. However, all 360 such costs are absent in social insurance as it is often implemented by the government 361 and the subscriptions to the scheme are made compulsory by legislation and is usually 362 incorporated as a trust fund with no intention of making and/or distributing profit 363 out of it. Only two types of costs are associated with the social insurance: First is 364 the settlement of claims put forward by the policy holders and the second is the day 365 to day operating expenses which includes payments of salaries of the employees, rent 366 and utility payments and things like these. In social insurance anything that remains 367 with the insurance companies after the payment of claims and operating expenditure 368 is retained in a trust fund which is used for future claim settlement and meeting up 369 upcoming operating expenditures. However, in commercial insurances the retained 370 earnings are either distributed upright amongst the stakeholders according to their 371 proportion of share holdings or are kept for future use by the insurance company 372 itself. In the later case it eventually adds to the capital base of the insurance 373 
company. In either case it is of no use to the policy holders who have actually paid 374 for this. Thus the commercial profit-oriented private/public insurance companies 375 behave more like a system without any memory: Policy holders do need to forget 376 about any extra premium they have paid in the previous periods and to pay the 377 premium in full during present period. Here, we argue that if the insurance scheme 378 is implemented as a not-for-profit trust fund (social insurance) instead of a for-profit 379 limited liability company (commercial insurance) then it will effectively and less 380 expensively hedge against unforeseen losses. If the profit of the insurance company is 381 retained instead of being distributed to the stockholders and invested in safe securities 382 like the government bonds then a fraction of all upcoming claims can be addressed 383 from the interest income of the accumulated profit which results into a lesser amount 384 of premiums for the policy holders to pay in future. In other way the policy holders 385 get to enjoy anything they have paid in excess as premiums with interest thereon in 386 the upcoming periods which lessens their burden of premiums. 387

To quantify the extent of extra premiums associated with the commercial insurances 389 we collect country-level time series data of premium collection, claim settlement and 390 operating expenditure of all commercial life and non-life insurance companies working 391 inside a particular country from OECD insurance database [28]. OECD insurance 392 database is the single most comprehensive insurance database to date that facilitates 393 country level insurance data from 2008 to 2018. We also collect time series data of 394 interest rate of government securities from IMF database [20]. We then subtract the 395 amount of claim payment and operating expenditures incurred during a particular 396 period from the premiums collected during the period. Anything in excess of claim 397 settlement and operating expenditures is the sheer profit of the insurances companies 398 which is then invested in the government securities at the existing rate. Profits and 399 interest there to are accumulated over the years and are reinvested in the government 400 bonds. Starting from 2008 we calculate the consolidated amount of country-wise 401 profits gathered by different commercial insurance companies up to year 2018. To 402 be precise we calculate the following quantities at country level:

$$
A P_{i}=\sum_{j=2008}^{2018}\left(P_{i j}-C_{i j}-O E_{i j}\right) \times\left(1+d_{i j}\right)
$$

where $A P_{i}$ is the accumulated profit of all the insurance companies working 404 inside country $i, P_{i j}, C_{i j}$ and $O E_{i j}$ represent the combined sum of premium collected, 405 claim settled and operating expenditure incurred during year $j$ by all the insurance 406 companies in country $i . d_{i j}$ represents interest rate on government securities in 407 
country $i$ during year $j$. A sneak peek of what is going on here is depicted in Fig: 2408 and 3 .

Figure 2: Country-level Data of Accumulated Profit (AP) of All Commercial Insurance Companies for USA

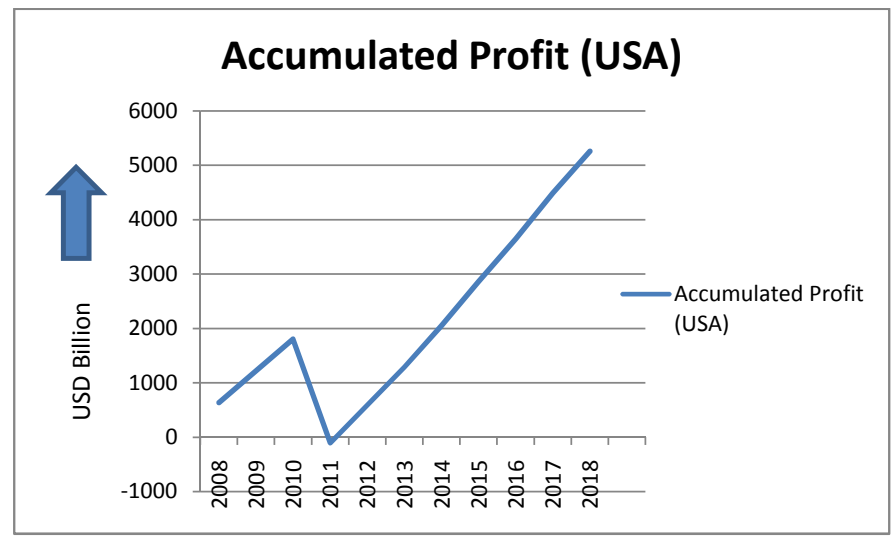

Figure 3: Country-level Data of Accumulated Profit (AP) of All Commercial Insurance Companies for Different OECD Countries

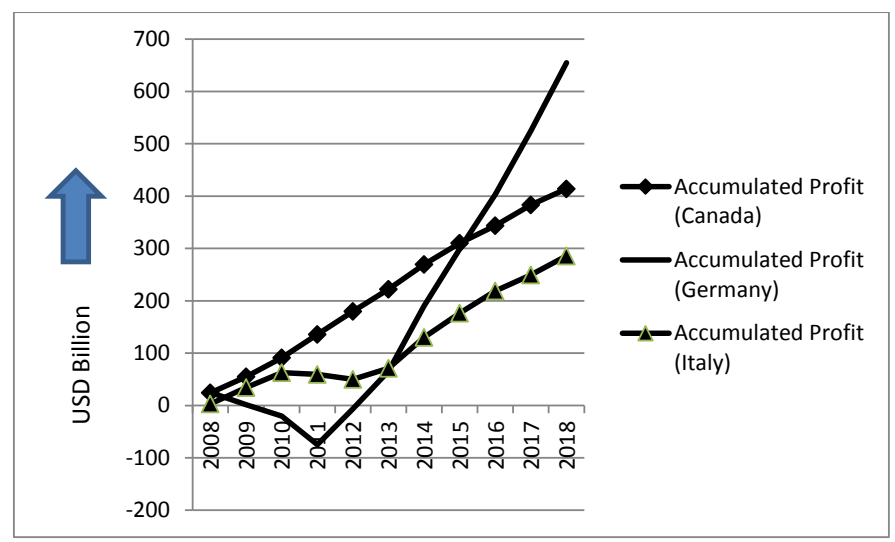

Fig: 2 shows the aggregate amount of excess premiums with up to date interest 410 thereon received by all the US insurance companies during 2008-2018. It has been 411 observed from Fig: 2 that the value of $A P$ is positive throughout the sampling interval ${ }_{412}$ except for 2011 when it becomes negative for a short while. The negative value of ${ }_{413}$ $A P$ in 2011 stems from the fact that during this period US insurance companies ${ }_{414}$ settled down a surprisingly high volume of claims with a consolidated value of $\$ 3.70 \quad 415$ trillion whereas the premium collection and operating expenditures totaled to $\$ 2.15 \quad 416$ 
and $\$ 0.31$ trillion respectively. The situation changes abruptly after 2011 and the 417 $A P$ becomes positive from the next period reaching a staggering sum of $\$ 5.26$ trillion 418 in 2018.

Fig: 3 presents the value of accumulated profit (AP) for 03 (three) other OECD 420 countries including Canada, Germany and Italy. From Fig: 3 it is evident that the 421 Canadian insurance companies during 2008-2018 have successfully raised sufficient 422 amount of premiums to cover up both their periodic claim settlement and operating 423 expenditures. Thus the accumulated profit (AP) profit is found to be positive ${ }_{424}$ throughout ultimately reaching $\$ 414.07$ billion in 2018 .

For German data AP has been found negative during 2010, 2011 and 2012. 426 During 2010 and 2011 German commercial insurance companies raised $\$ 241.05$ and 427 $\$ 255,71$ billion of premiums whereas the claim settlement and operating expenditure 428 involved amounted to $\$ 262.24$ and $\$ 308.66$ billion respectively. As the premiums 429 earned are not sufficient to cover up entire claim settlement and operating expenditures 430 of the respective year $A P$ becomes negative for 2010 and 2011. However, premium 431 collection exceeds claim settlement and operating expenditures during 2012 and the 432 negative value of $A P$ is partially compensated. Nonetheless $A P$ remains negative in 433 2012 and after that it becomes positive and eventually rises steadily up to $\$ 654.89434$ billion during 2018.

It can be seen from Fig: 3 that Italian insurance companies are also successful 436 in raising enough premiums to meet up operating expenditures and annual claim 437 settlement resulting into consistent positive values of $A P$ with upward trend. During 438 2018 the value of $A P$ for Italian commercial insurance companies reaches nearly 439 $\$ 285.93$ billion starting from 2008 .

440

So from the above discussion it has been observed that over the years the commercial ${ }_{441}$ insurance companies in all the 04 (four) jurisdictions have raised substantial amounts 442 of premiums which are more than sufficient to cover up total operating expenditures 443 and claim settlement in the respective periods. The total amount of premiums 444 collected after being offset by the operating expense and claim settlement are assumed $\quad 445$ to be invested in government securities which are widely regarded as the safest kind ${ }_{446}$ of investments and are backed by the sovereign guarantee. Cumulative sum of excess 447 premiums thus collected till 2018 with opportunity cost there to have been found to 448 be $\$ 5.26$ trillion, $\$ 414.07$ billion, $\$ 654.89$ billion and $\$ 285.93$ billion for USA, Canada, 449 Germany and Italy. If the insurance schemes in these regions were implemented as a 450 not-for-profit trust fund instead of a conventional commercial profit-based schemes 451 then it would have resulted into $\$ 5.26$ trillion, $\$ 414.07$ billion, $\$ 654.89$ billion and 452 $\$ 285.93$ billion savings for policy holders in USA, Canada, Germany and Italy. $\quad 453$ 


\section{$7 \quad$ Forecasting Methodology}

In the previous section we have seen that the accumulated profits (AP) gathered by ${ }_{455}$ different commercial insurance companies during 2008-2018 amount to $\$ 5.26$ trillion 456 for USA, $\$ 414.07$ billion for Canada, $\$ 654.89$ billion for Germany and $\$ 285.93$ billion 457 for Italy. In all cases profits show distinctively upward trends. In this section we 458 will analyze the trends of these accumulated profits over the upcoming years using ${ }_{459}$ ARIMA-GARCH framework. A brief description of the ARIMA-GARCH framework ${ }_{460}$ used for forecasting is given below. $\quad 461$

The first step of our analysis is to select a suitable ARIMA representation of the ${ }_{462}$ time series to be forecasted in order to model the conditional mean of the $A P$. In ${ }_{463}$ ARIMA framework we are meant to deal with stationary time series only. So, to begin 464 our analysis we perform an appropriate number of differencing on our AP time series $\quad 465$ to induce stationarity on it. The next step is to identify a suitable ARMA model with 466 autoregressive and moving average terms by analyzing the Autocorrelation Function 467 $(\mathrm{ACF})$ and Partial Autocorrelation Function (PACF).

To do so we plot the ACF and PACF of the appropriately differenced $A P$ series 469 and examine the patterns. If both the plots of ACF and PACF show exponential 470 decay then the underlying series is supposed to contain both autoregressive and 471 moving average terms. On the other hand if only the ACF plot shows exponential 472 decay whereas the PACF plot shows significant spikes at the first lags which disappear $\quad 473$ quite abruptly then the data are said to be generated from a purely autoregressive 474 process. However, if the PACF plot shows exponential decay and ACF plot shows 475 significant spikes during the first few lags then the process is assumed to be a moving 476 average one. Once we are done with the nature of the process we take appropriate ${ }_{477}$ autoregressive and/or moving average terms and estimate the model using ordinary 478 least squares. After the model is estimated we plot the correlogram of the residuals 479 and note down the lag numbers that still contain substantial information. The 480 model estimated in the first step is then modified to include additional autoregressive 481 and moving average terms. The process continues until and unless no substantial 482 information content is left in the residuals of the estimated model as can be seen from 483 the correlogram plot of the residuals. However, in doing so we always strive to find 484 a rather parsimonious model to fit our data instead of an over-parameterized one. 485 The over-parameterized model may seem to perform well on the training data set. ${ }_{486}$ Nonotheless it is supposed to suffer heavily when it is used to forecast beyond the 487 training range. To select an appropriate model in this gradual step-by-step procedure 488 we use Akaike Information Criteria (AIC) to compare amongst the probable models. ${ }_{489}$ Model that minimizes the AIC will be preferred. 
Once the model has been selected we estimate it using standard OLS and note ${ }_{491}$ down the t-Statistics and p-values corresponding to different autoregressive and ${ }_{492}$ moving average terms. A specific autoregressive/moving average term is said to ${ }_{493}$ be significant if its p-value is less than 5\%. We also note down SIGMASQ which 494 represents the volatility of the estimated model. When weighting one model against 495 the other we prefer the one with the lower volatility (SIGMASQ). 496

In the next step we check for serial correlation and heteroscedasticity in the 497 residuals of the estimated models. To do so we check the value of the Durbin-Watson ${ }_{498}$ Statistic of the estimated model. If the Durbin-Watson Statistic is close to 2 then ${ }_{499}$ the model is assumed to be free from the problem of serial correlation. On the other 500 hand to check for heteroscedasticity in the residuals we perform ARCH-LM test. 501 The null hypothesis of the ARCH-LM test is that the residuals are homoscedastic. If ${ }_{502}$ the null hypothesis cannot be rejected @5\% level then we know that our estimated 503 ARIMA model does not suffers from the problem of heteroscedasticity which is a 504 desirable trait. In the absence of heteroscedasticity we forecast the series using our 505 estimated model up until 2025. 506

On the other hand if the null hypothesis of the ARCH-LM test can be rejected 507 @5\% level then it implies our estimated ARIMA model suffers from heteroscedasticity. 508 To overcome this problem we estimate an ARIMA-GARCH model instead of a 509 purely ARIMA model. ARIMA-GARCH model comes up with two different linear 510 equations: The first one is an ARMA representation of the appropriately differnced 511 series intended to capture the conditional mean of the seris while the second equation 512 is intended to capture the conditional variance. $\quad 513$

Once the appropriate ARIMA-GARCH model has been estimated it is then used 514 to forecast the time series into the future.

\section{Forecasting Results}

Details of the ARIMA representation selected for modeling US data are presented 517 in Table: 1. From Table: 1 we see that the model contains 02 (two) autoregressive 518 terms $\mathrm{AR}(1), \mathrm{AR}(2)$ and 01 (one) moving average term $\mathrm{MA}(4)$. It is also noted 519 that the US data are differenced 02 (two) times before being fed into the model. 520 Model estimation section of Table: 1 presents the estimated coefficients along with ${ }_{521}$ the standard errors, t-Statistics and the corresponding p-values. It is evident that all 522 the p-values corresponding to $\mathrm{AR}(1), \mathrm{AR}(2), \mathrm{MA}(4)$ and SIGMASQ are significant 523 @5\% level. We then use the estimated model to produce the forecasted values of $A P \quad{ }_{524}$ for US data up until 2025 and the forecasted results are presented in Fig: 4. From 525 Fig: 4 it is evident that the $A P$ continues to show an upward trend reaching $\$ 16.70 \quad 526$ 
Table 1: ARIMA Model Used For Forecasting Accumulated Profit for Commercial For-Profit US Insurance Companies

\begin{tabular}{|c|c|c|c|c|}
\hline \multicolumn{5}{|l|}{ Model Specification: } \\
\hline Country & Time Range & Differencing & AR terms & MA terms \\
\hline USA & 2008M01-2018M01 & 2 & $\mathrm{AR}(1), \mathrm{AR}(2)$ & MA(4) \\
\hline \multicolumn{5}{|l|}{ Model Estimation: } \\
\hline Variable & Coefficient & Std. Error & t-Statistic & Prob. \\
\hline $\operatorname{AR}(1)$ & $-9.56 \mathrm{E}-01$ & 2.33E-02 & -40.9519 & 0 \\
\hline $\operatorname{AR}(2)$ & -0.496954 & 0.054822 & -9.064918 & 0 \\
\hline $\mathrm{MA}(4)$ & 0.161493 & 0.06687 & 2.415037 & 0.0173 \\
\hline SIGMASQ & 2.257607 & 0.081629 & 27.65685 & 0 \\
\hline \multicolumn{5}{|l|}{ Model Performance: } \\
\hline R-Squared & & & & 0.547755 \\
\hline Adj. R-Squared & & & & 0.535957 \\
\hline Durbin-Watson Statistic & & & & 2.253981 \\
\hline Remark & & & & No Serial Correlation \\
\hline Obs. R squared (ARCH test) & & & & 44.20702 \\
\hline p-value & & & & 0 \\
\hline Remark (@5\%) & & & & Presence of ARCH Effect \\
\hline
\end{tabular}

Figure 4: Actual and ARIMA Forecasted Accumulated Profit (AP) for Commercial For-Profit US Insurance Companies

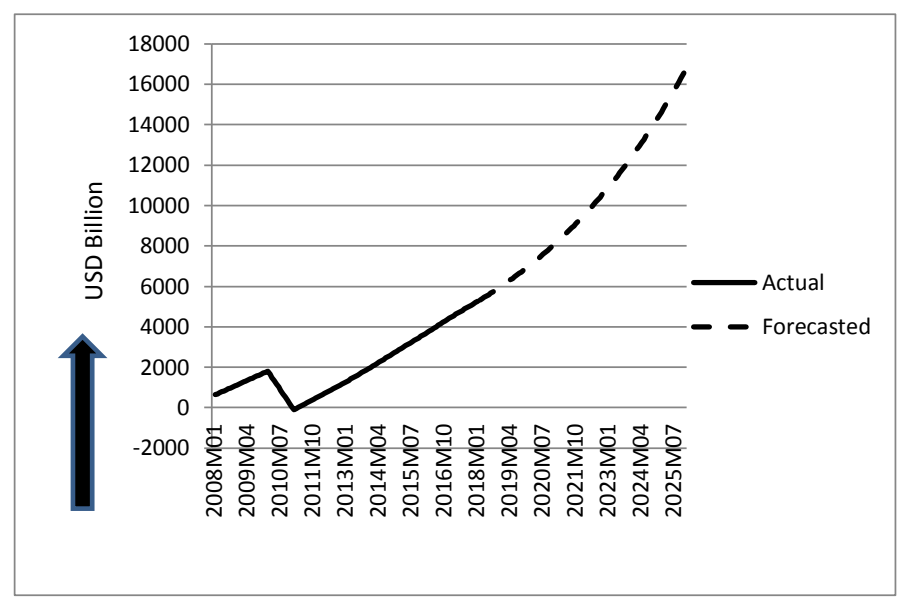


trillion in 2025. It implies that the extra premiums born to the insurance policy 527 holders in US during 2008-2025 along with the opportunity cost there on amount to 528 $\$ 16.70$ trillion. If the insurance scheme was operated using a social principle instead 529 of a for-profit commercial one then the policy holders would have saved around $\$ 16.70 \quad 530$ trillion during 2008-2025. Moreover, from the model performance section we can see 531 that the R-Squared and Adjusted R-Squared values of the fitted model are 0.55 and 532 0.54 respectively which represent a good fit. Durbin-Watson Statistic of the model 533 is found to be nearly 2.25. As the DW Statistic is close to 2.00 we can conclude that 534 the model does not suffer much from the problem of serial correlation in its residuals 535 which is a desirable trait. We also check for the presence of heteroscedasticity in ${ }_{536}$ the residuals of the estimated model using ARCH-LM test. Obs. R-Squared for the ${ }_{537}$ ARCH test is found to be 44.21 with p-value of 0.0 which results into the rejection of 538 the null hypothesis @ $5 \%$ level. Rejection of null hypothesis for the ARCH-LM test 539 indicates the presence of strong heteroscedasticity in the residuals of the estimated 540 model. Presence of heteroscedasticity in the residuals implies that our fitted ARIMA ${ }_{541}$ model may not be appropriate for producing the forecasts. Rather an appropriately ${ }_{542}$ fitted ARIMA-GARCH model would better serve the purpose.

Figure 5: Actual and ARIMA-GARCH Forecasted Accumulated Profit (AP) for Commercial For-Profit US Insurance Companies

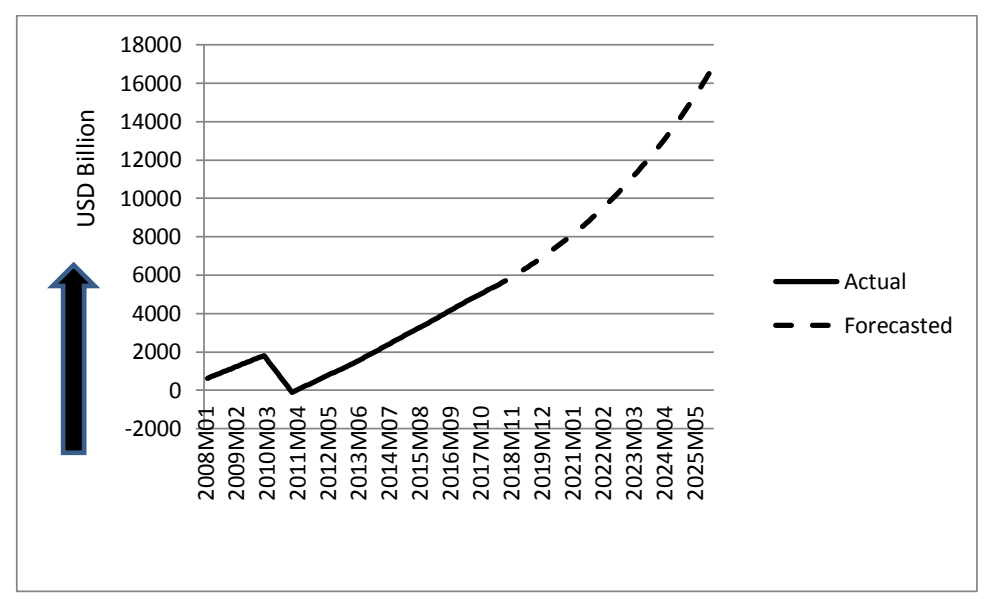

Specification, estimation and performance of the estimated ARIMA-GARCH 544 model are presented in Table: 2. The estimated model retains the previous version's 545 ARMA structure by including terms like $\mathrm{AR}(1), \mathrm{AR}(2)$ and $\mathrm{MA}(4)$. Like the previous 546 ARIMA mdoel the coefficients of $\mathrm{AR}(1), \mathrm{AR}(2)$ and $\mathrm{MA}(4)$ are found to be significant $\quad 547$ @5\% level. From the variance equation we can see that the coefficient of the squared 548 lagged residual is also significant @5\% level which speaks for the validity of the 549 
Table 2: ARIMA-GARCH Model Used For Forecasting Accumulated Profit for Commercial For-Profit US Insurance Companies

\begin{tabular}{|c|c|c|c|c|}
\hline $\begin{array}{l}\text { Model Specification: } \\
\text { Country } \\
\text { USA }\end{array}$ & $\begin{array}{c}\text { Time Range } \\
\text { 2008M01-2018M01 }\end{array}$ & $\begin{array}{c}\text { Differencing } \\
2\end{array}$ & $\begin{array}{c}\text { AR terms } \\
\operatorname{AR}(1), \operatorname{AR}(2)\end{array}$ & $\begin{array}{l}\text { MA terms } \\
\text { MA }(4)\end{array}$ \\
\hline $\begin{array}{l}\text { Model Estimation: } \\
\text { Variable }\end{array}$ & Coefficient & Std. Error & z-Statistic & Prob. \\
\hline $\begin{array}{l}\operatorname{AR}(1) \\
\operatorname{AR}(2) \\
\operatorname{MA}(4)\end{array}$ & $\begin{array}{c}-1.357639 \\
-0.357641 \\
0.016176\end{array}$ & $\begin{array}{l}6.62 \mathrm{E}-01 \\
1.74 \mathrm{E}-01 \\
4.03 \mathrm{E}-03\end{array}$ & $\begin{array}{c}-2.051524 \\
-2.051601 \\
4.015446\end{array}$ & $\begin{array}{l}0.0402 \\
0.0402 \\
0.0001\end{array}$ \\
\hline $\begin{array}{l}\text { Variance Equation: } \\
\text { Variable } \\
\mathrm{C} \\
\operatorname{RESID}(-1)^{\wedge} 2\end{array}$ & $\begin{array}{c}\text { Coefficient } \\
1.51 \mathrm{E}-04 \\
3.62807\end{array}$ & $\begin{array}{c}\text { Std. Error } \\
5.08 \mathrm{E}-06 \\
1.061045\end{array}$ & $\begin{array}{c}\text { z-Statistic } \\
29.67852 \\
3.419337\end{array}$ & $\begin{array}{c}\text { Prob. } \\
0 \\
0.0006\end{array}$ \\
\hline $\begin{array}{l}\text { Model Performance: } \\
\text { R-Squared } \\
\text { Adj. R-Squared } \\
\text { Durbin-Watson Statistic } \\
\text { Remark } \\
\text { Obs. R squared for ARCH test } \\
\text { p-value } \\
\text { Remark (@5\%) }\end{array}$ & & & & $\begin{array}{c}0.291933 \\
0.279725 \\
2.103593 \\
\text { No Serial Correlation } \\
0.008869 \\
0.925 \\
\text { No ARCH effect }\end{array}$ \\
\hline
\end{tabular}

estimated ARIMA-GARCH model. We then use the model to forecast $A P$ for US 550 data till 2025 and the forecasted results are presented in Fig: 5. From Fig: 5 we 551 see that $A P$ will reach approximately $\$ 16.82$ trillion during 2025 which is very close ${ }_{552}$ to previous ARIMA forecast (previous result was $\$ 16.70$ trillion). Moreover, from ${ }_{553}$ Fig: 4 and 5 we see that the shapes for both ARIMA and ARIMA-GARCH forecast ${ }_{554}$ are quite similar and almost equal in values. However, the ARIMA-GARCH model 555 entails relatively smaller R-Squared and Adjusted R-Squared values (0.29 and 0.28556 respectively). Instead of the fact that the R-Squared and Adjusted R-Squared values ${ }_{557}$ are lower than that of ARIMA model, the estimated ARIMA-GARCH model is free ${ }_{558}$ from serial correlation and heteroscedasticity as evident from the model performance 559 section of Table: 2 .

In the next step we will analyze the trend of accumulated profit $(A P)$ for Canadian 561 data. Our fitted ARIMA model for forecasting Canadian AP comprises 01 (one) ${ }_{562}$ autoregressive term $(\mathrm{AR}(1))$ and 01 (one) moving average term $(\mathrm{MA}(1))$ and we take ${ }_{563}$ 
Table 3: ARIMA Model Used For Forecasting Accumulated Profit for Commercial For-Profit Canadian Insurance Companies

\begin{tabular}{|c|c|c|c|c|}
\hline \multicolumn{5}{|l|}{ Model Specification: } \\
\hline Country & Time Range & Differencing & AR terms & MA terms \\
\hline Canada & 2008M01-2018M01 & 2 & $\operatorname{AR}(1)$ & MA(1) \\
\hline \multicolumn{5}{|l|}{ Model Estimation: } \\
\hline Variable & Coefficient & Std. Error & t-Statistic & Prob. \\
\hline $\mathrm{AR}(1)$ & 0.99227 & 0.003902 & 254.2854 & 0 \\
\hline MA(1) & -0.609817 & 0.03876 & -15.73322 & 0 \\
\hline SIGMASQ & $1.66 \mathrm{E}-06$ & $6.79 \mathrm{E}-08$ & 24.42149 & 0 \\
\hline \multicolumn{5}{|l|}{ Model Performance: } \\
\hline R-Squared & & & & 0.490082 \\
\hline Adj. R-Squared & & & & 0.48129 \\
\hline Durbin-Watson Statistic & & & & 2.085224 \\
\hline Remark & & & & No Serial Correlation \\
\hline Obs. R squared for ARCH test & & & & 1.918524 \\
\hline p-value & & & & 0.166 \\
\hline Remark (@5\%) & & & & No ARCH effect \\
\hline
\end{tabular}

Figure 6: Actual and ARIMA Forecasted Accumulated Profit (AP) for Commercial For-Profit Canadian Insurance Companies

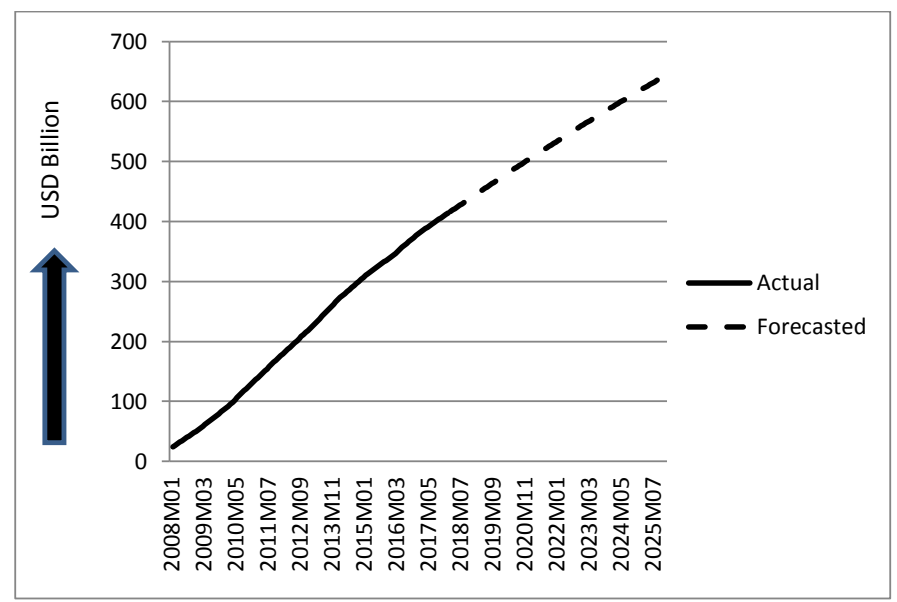


second difference of $A P$ before fitting it into ARIMA framework. The coefficients of 564 the estimated model with the t-Statistics and corresponding $\mathrm{p}$-values are presented 565 in Table: 3. From Table: 3 we can see that both $\mathrm{AR}(1), \mathrm{MA}(1)$ along with the 566 SIGMASQ are very significant. We use this model to forecast $A P$ for Canadian data 567 up to 2025 and the forecasting results are presented in Fig: 6. From 6 we can see that 568 $A P$ continues to show an upward trend although its growth rate is a bit dampened 569 over the course. However, it reaches $\$ 643.78$ billion during 2025 which implies 570 policy holders of commercial insurances in Canada pay around $\$ 643.78$ billion in 571 excess premiums during the period 2008-2025 as compared to social insurance. Thus 572 $\$ 643.78$ billion could have been saved by the insurance policy holders if the scheme 573 was implemented using the principles of social insurances. Moreover, R-Squared 574 and Adjusted R-Squared of the model are found to be 0.49 and 0.48 respectively 575 which represent a reasonably good fit. Durbin-Watson Statistic of the fitted model 576 is found to be 2.08 which is very close to 2.00. This implies the model is free from 577 serial correlation. Last but not the least the Obs. R-Squared of the ARCH-LM 578 test is 0.166 or $16.60 \%$. So, the null hypothesis cannot be rejected @ $5 \%$ level which 579 means the residuals are homoscedastic and our fitted ARIMA model is appropriate 580 for forecasting.

Figure 7: Actual and ARIMA Forecasted Accumulated Profit (AP) for Commercial For-Profit German Insurance Companies

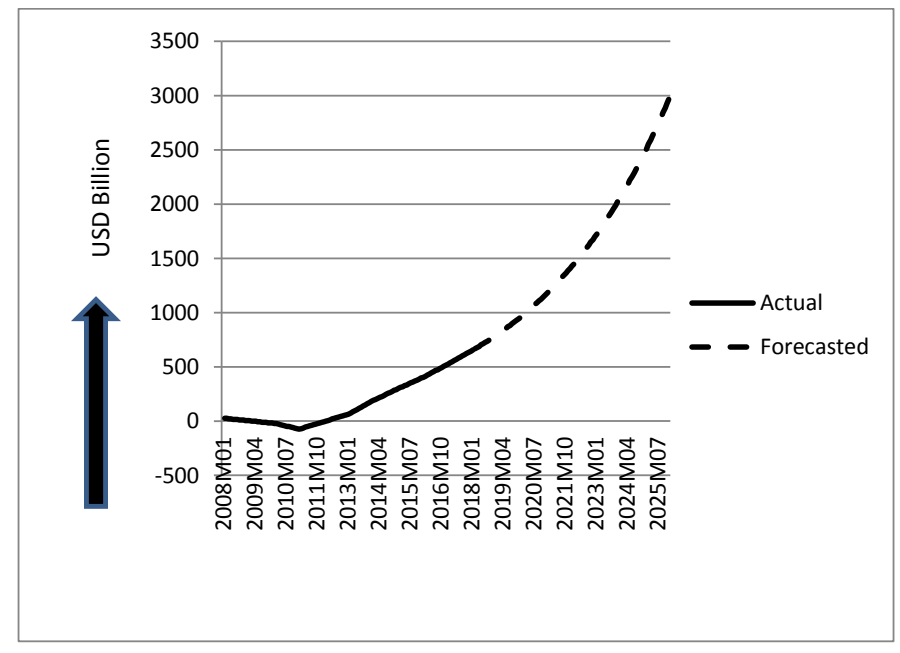

Next we will see how the accumulated profit $(A P)$ for German insurance companies 582 evolves over time. Our ARIMA framework for modeling conditional mean of $A P$ for 583 German data comprises $\mathrm{AR}(1), \mathrm{AR}(2)$ and $\mathrm{MA}(4)$ terms. The estimated model 584 
Table 4: ARIMA Model Used For Forecasting Accumulated Profit for Commercial For-Profit German Insurance Companies

\begin{tabular}{|lcccc|}
\hline Model Specification: & & & \\
Country & $\begin{array}{c}\text { Time Range } \\
\text { 2008M01-2018M01 }\end{array}$ & $\begin{array}{c}\text { Differencing } \\
\text { Germany }\end{array}$ & $\begin{array}{c}\text { AR terms } \\
\text { AR(1), AR(2) }\end{array}$ & $\begin{array}{c}\text { MA terms } \\
\text { MA }(4)\end{array}$ \\
\hline Model Estimation: & & & & \\
Variable & Coefficient & Std. Error & t-Statistic & Prob. \\
AR(1) & -0.939801 & 0.026118 & -35.98291 & 0 \\
AR(2) & -0.485115 & 0.06651 & -7.293895 & 0 \\
MA(4) & 0.149691 & 0.071431 & 2.095595 & 0.0383 \\
SIGMASQ & 1.531928 & 0.059928 & 25.56271 & 0 \\
& & & & \\
Model Performance: & & & & 0.536582 \\
R-Squared & & & & 0.524493 \\
Adj. R-Squared & & & & 2.248542 \\
Durbin-Watson Statistic & & & & No Serial Correlation \\
Remark & & & & 39.53258 \\
Obs. R squared for ARCH test & & & & 0 \\
p-value & & & & Presence of ARCH Effect \\
Remark @5\%) & & & & \\
\hline
\end{tabular}

with coefficient t-Statistics and p-values are presented in Table: 4 . From Table: 4585 it is evident that $\mathrm{AR}(1), \mathrm{AR}(2), \mathrm{MA}(4)$ and SIGMASQ are significant @ $5 \%$ level. 586 This implies each of the variables in our fitted parsimonious model exerts significant 587 influence on the dependent variable. Moreover, R-Squared and Adjusted R-Squared 588 values of the model are found to be 0.54 and 0.52 respectively which represent a good 589 fit. The model is somewhat free from serial correlation as can be seen from the value 590 of Durbin-Watson Statistic in Table: 4. However, it suffers from heteroscedasticity 591 as evident from the results of ARCH-LM test. Although the model is faulty a little 592 bit due to the presence of uncaptured heteroscedasticity in the residuals we use it 593 for forecasting $A P$ and compare the forecasted results to that of ARIMA-GARCH ${ }_{594}$ model. The forecasted results are presented in Fig: 7. Fig: 7 reveals that up to 595 2025 AP for German data reaches nearly $\$ 2.98$ trillion. The staggering sum of $\$ 2.98596$ trillion could have been saved by the policy holders if they chose to pursue a social 597 insurance scheme instead of a commercial for-profit one. 598

Estimation results of ARIMA-GARCH model to forecast $A P$ for German data 599 are presented in Table: 5. From Table: 5 it is evident that $\operatorname{AR}(1), \operatorname{AR}(2)$ and $\mathrm{MA}(4) \quad 600$ 
Table 5: ARIMA-GARCH Model Used For Forecasting Accumulated Profit for Commercial For-Profit German Insurance Companies

\begin{tabular}{|c|c|c|c|c|}
\hline $\begin{array}{l}\text { Model Specification: } \\
\text { Country } \\
\text { Germany }\end{array}$ & $\begin{array}{c}\text { Time Range } \\
\text { 2008M01-2018M01 }\end{array}$ & $\begin{array}{c}\text { Differencing } \\
2\end{array}$ & $\begin{array}{c}\text { AR terms } \\
\operatorname{AR}(1), \operatorname{AR}(2)\end{array}$ & $\begin{array}{l}\text { MA terms } \\
\quad \operatorname{MA}(4)\end{array}$ \\
\hline $\begin{array}{l}\text { Model Estimation: } \\
\text { Variable } \\
\operatorname{AR}(1) \\
\operatorname{AR}(2) \\
\operatorname{MA}(4)\end{array}$ & $\begin{array}{c}\text { Coefficient } \\
-0.594289 \\
-0.276176 \\
0.025253\end{array}$ & $\begin{array}{c}\text { Std. Error } \\
3.51 \mathrm{E}-02 \\
1.34 \mathrm{E}-02 \\
1.04 \mathrm{E}-02\end{array}$ & $\begin{array}{c}\text { z-Statistic } \\
-16.90876 \\
-20.67768 \\
2.43715\end{array}$ & $\begin{array}{l}\text { Prob. } \\
\quad 0 \\
0 \\
0.0148\end{array}$ \\
\hline $\begin{array}{l}\text { Variance Equation: } \\
\text { Variable } \\
\mathrm{C} \\
\operatorname{RESID}(-1)^{\wedge} 2\end{array}$ & $\begin{array}{c}\text { Coefficient } \\
8.28 \mathrm{E}-08 \\
14.27835\end{array}$ & $\begin{array}{c}\text { Std. Error } \\
2.26 \mathrm{E}-07 \\
0.821815\end{array}$ & $\begin{array}{c}\text { z-Statistic } \\
0.365566 \\
17.37417\end{array}$ & $\begin{array}{l}\text { Prob. } \\
0.7147 \\
0\end{array}$ \\
\hline $\begin{array}{l}\text { Model Performance: } \\
\text { R-Squared } \\
\text { Adj. R-Squared } \\
\text { Durbin-Watson Statistic } \\
\text { Remark } \\
\text { Obs. R squared for ARCH test } \\
\text { p-value } \\
\text { Remark (@5\%) }\end{array}$ & & & & $\begin{array}{c}0.462645 \\
0.45338 \\
2.828434 \\
\text { Serrial Correlation Exists } \\
0.044879 \\
0.8322 \\
\text { No ARCH effect }\end{array}$ \\
\hline
\end{tabular}

are significant @ $5 \%$ level. Moreover, from the variance equation we can see that 601 the coefficient of the squared (lagged) residuals is also significant @ $5 \%$ level which 602 demonstrates heteroscedasticity being nicely handled by the model. Although the 603 fitted ARIMA-GARCH model is free from residual heteroscedasticity (see the results 604 of ARCH-LM test presented in Table: 5) it suffers a little bit from serial correlation 605 problem (see the value of DW Statistic presented in Table: 5). We then use the 606 estimated model to forecast the behavior of $A P$ till 2025 and the forecasted results 607 are presented in Fig: 8. From Fig: 8 we can see that the $A P$ reaches nearly $\$ 2.99608$ trillion during 2025 which is very close to the ARIMA forecasted value ( $\$ 2.98$ trillion). $\quad 609$ So the forecasting results imply that German insurance policy holders will pay nearly 610 $\$ 3.00$ trillion in excess premiums owing to their purchase of commercial insurances 611 which would have been saved if it were possible to purchase a social alternative. $\quad 612$

Finally we will forecast accumulated profit $(A P)$ for Italian data. Our parsimonious 613 ARIMA framework to model conditional mean of $A P$ consists of only one autoregressive 614 term namely $A R(1)$. To induce stationarity in the data the $A P$ series is differenced 615 
Figure 8: Actual and ARIMA-GARCH Forecasted Accumulated Profit (AP) for Commercial For-Profit German Insurance Companies

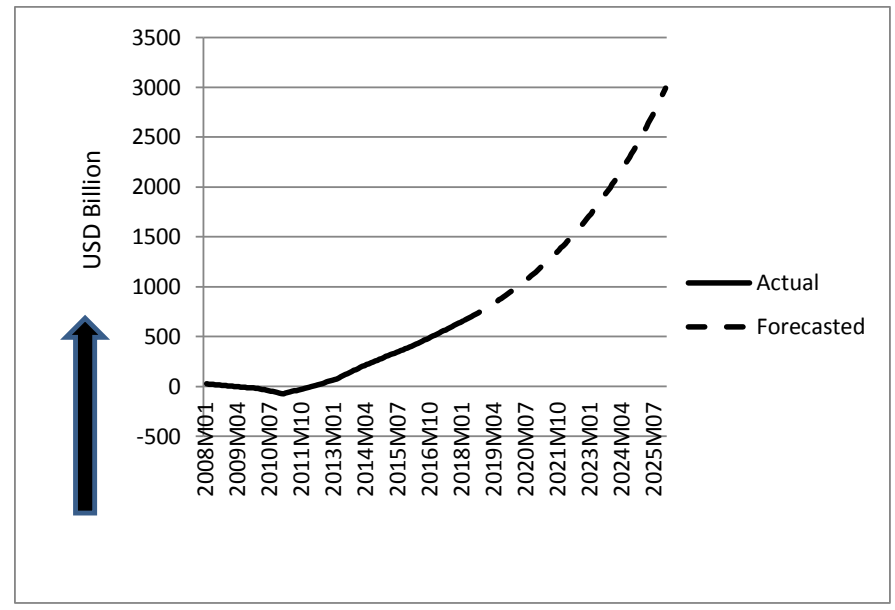

Table 6: ARIMA Model Used For Forecasting Accumulated Profit for Commercial For-Profit Italian Insurance Companies

\begin{tabular}{|c|c|c|c|c|}
\hline \multicolumn{5}{|l|}{ Model Specification: } \\
\hline Country & Time Range & Differencing & AR terms & MA terms \\
\hline Italy & 2008M01-2018M01 & 2 & $\mathrm{AR}(1)$ & - \\
\hline \multicolumn{5}{|l|}{ Model Estimation: } \\
\hline Variable & Coefficient & Std. Error & t-Statistic & Prob. \\
\hline $\mathrm{AR}(1)$ & 0.988426 & 0.006057 & 163.2008 & 0 \\
\hline SIGMASQ & 0.0003 & $1.10 \mathrm{E}-05$ & 27.30812 & 0 \\
\hline \multicolumn{5}{|l|}{ Model Performance: } \\
\hline R-Squared & & & & 0.565959 \\
\hline Adj. R-Squared & & & & 0.56225 \\
\hline Durbin-Watson Statistic & & & & 2.189133 \\
\hline Remark & & & & No Serial Correlation \\
\hline Obs. R squared for ARCH test & & & & 4.106784 \\
\hline p-value & & & & 0.0427 \\
\hline Remark (@5\%) & & & & Presence of ARCH Effect \\
\hline
\end{tabular}

02 (two) times before being fed into the model. Coefficient of $A R(1)$ along with the 616 SIGMASQ are very significant as can be seen from their p-values as shown in Table: ${ }_{617}$ 
Figure 9: Actual and ARIMA Forecasted Accumulated Profit (AP) for Commercial For-Profit Italian Insurance Companies

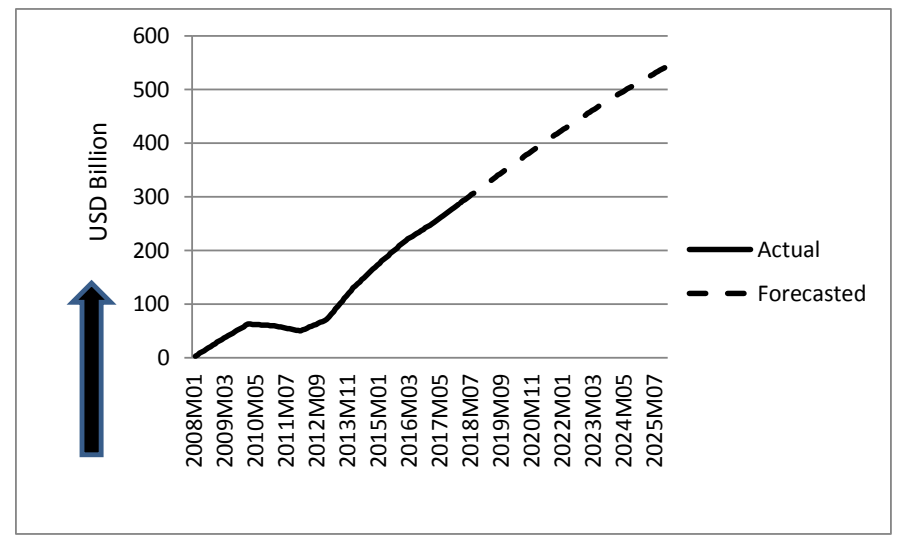

6. R-Squared and Adj. R-Squared values of the model are found to be 0.57 and $0.56 \quad 618$ which are decent and demonstrate that our chosen ARIMA model fits the data well. ${ }_{619}$ The value of Durbin-Watson Statistic for the estimated model is found to be 2.19620 which is very close to 2.00. DW Statistic symbolizes the absence of serial correlations ${ }_{621}$ amongst the residuals of the estimated model which validates the model. However, ${ }_{622}$ the model suffers from the problem of heteroscedastic residuals as can be seen from ${ }_{623}$ the results of the ARCH-LM test. As the residuals are found to be heteroscedastic ${ }_{624}$ we also build an appropriate ARIMA-GARCH model and compare its performance ${ }_{625}$ to that of the ARIMA model used in the first place. ARIMA forecasting reveals that ${ }_{626}$ the value of $A P$ for Italian data will reach approximately $\$ 542.55$ billion during $2025 \quad 627$ while still sharply pointing upward. 628

On the other hand the ARIMA-GARCH model predicts that the value of $A P{ }_{629}$ will reach nearly $\$ 772.84$ billion during 2025 . The forecasted values produced by 630 the ARIMA-GARCH model are graphically presented in Fig: 10. The details of the 631 estimated ARIMA-GARCH model are documented in Table: 7. From Table: 7 we 632 can see that the coefficient of the $A R(1)$ in the equation of the conditional mean is 633 highly significant with p-value of zero. Meanwhile, the conditional variance equation ${ }_{634}$ reveals that the coefficient of the squared residual is also very significant as evident 635 from the z-Statistic and corresponding p-value. Moreover, the R-Squared and the 636 Adj. R-Squared are found to be 0.39 which denote a reasonably good fit. However, ${ }_{637}$ the residuals of the model suffer from serial correlation to some extent as evident from 638 the value of Durbin-Watson Statistic. But, the ARCH components have been nicely ${ }_{639}$ captured by the selected variance equation and no remnant of heteroscedasticity is 640 observed in the estimated residuals.

641 
Table 7: ARIMA-GARCH Model Used For Forecasting Accumulated Profit for Commercial For-Profit Italian Insurance Companies

\begin{tabular}{|c|c|c|c|c|}
\hline $\begin{array}{l}\text { Model Specification: } \\
\text { Country } \\
\text { Italy }\end{array}$ & $\begin{array}{c}\text { Time Range } \\
\text { 2008M01-2018M01 }\end{array}$ & $\begin{array}{l}\text { Differencing } \\
\quad 2\end{array}$ & $\begin{array}{l}\text { AR terms } \\
\operatorname{AR}(1)\end{array}$ & $\begin{array}{c}\text { MA terms } \\
-\end{array}$ \\
\hline $\begin{array}{l}\text { Model Estimation: } \\
\text { Variable } \\
\operatorname{AR}(1)\end{array}$ & $\begin{array}{c}\text { Coefficient } \\
0.588995\end{array}$ & $\begin{array}{c}\text { Std. Error } \\
0.119069\end{array}$ & $\begin{array}{c}\text { z-Statistic } \\
4.946657\end{array}$ & $\begin{array}{l}\text { Prob. } \\
\quad 0\end{array}$ \\
\hline $\begin{array}{l}\text { Variance Equation: } \\
\text { Variable } \\
\mathrm{C} \\
\operatorname{RESID}(-1)^{\wedge} 2\end{array}$ & $\begin{array}{c}\text { Coefficient } \\
5.95 \mathrm{E}-05 \\
0.424554\end{array}$ & $\begin{array}{l}\text { Std. Error } \\
2.00 \mathrm{E}-06 \\
0.134626\end{array}$ & $\begin{array}{c}\text { z-Statistic } \\
29.79371 \\
3.153586\end{array}$ & $\begin{array}{l}\text { Prob. } \\
0 \\
0.0016\end{array}$ \\
\hline $\begin{array}{l}\text { Model Performance: } \\
\text { R-Squared } \\
\text { Adj. R-Squared } \\
\text { Durbin-Watson Statistic } \\
\text { Remark } \\
\text { Obs. R squared for ARCH test } \\
\text { p-value } \\
\text { Remark (@5\%) }\end{array}$ & & & & $\begin{array}{c}0.392576 \\
0.392576 \\
1.65934 \\
\text { Serial Correlation Exists } \\
0.004033 \\
0.9494 \\
\text { No ARCH Effect }\end{array}$ \\
\hline
\end{tabular}

Figure 10: Actual and ARIMA-GARCH Forecasted Accumulated Profit (AP) for Commercial For-Profit Italian Insurance Companies

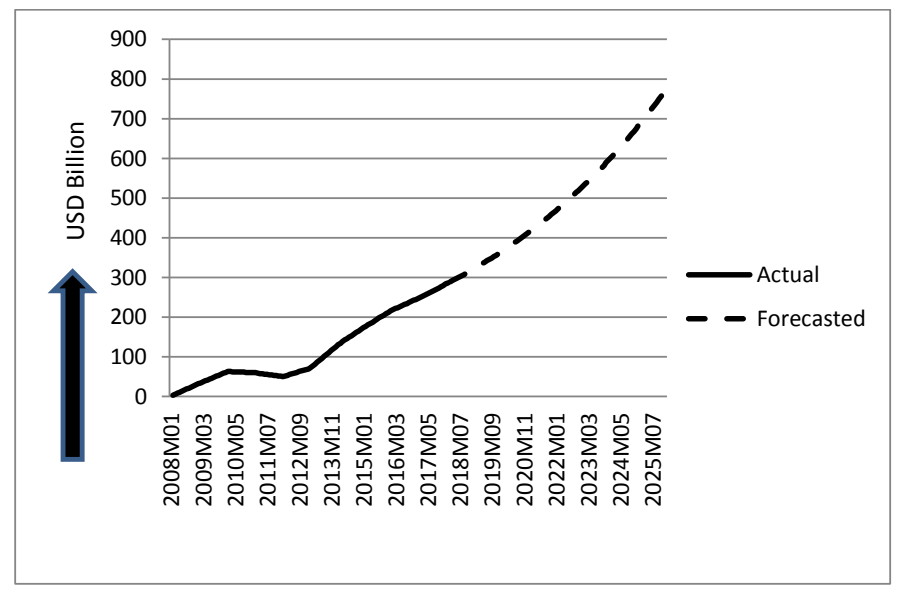




\section{Discussion}

From Fig: 2 and Fig: 3, we can see that the accumulated profits of the commercial 643 insurance companies have undergone a $V$-shaped recovery in and around 2011 . To us, ${ }_{644}$ the downturn from 2008 to 2011 in the accumulated profits is partly due to the global 645 financial crisis of the 2008 which initially started with the burst of the US housing 646 bubble, eventually devastated the global financial landscape and led to a cross-border ${ }_{647}$ banking crisis [36]. As the insurance companies are also financial institutions to 648 some extent and banks are their major customers, they are also affected by the crisis 649 that was initially centered in the USA but gradually spread across the world like a 650 bush fire. It is evident from Fig: 2 and 3 that the sharp decline of profits of the 651 insurance companies starting around 2008-2009 and the eventual recovery from 2011652 and onward are quite evident for US, German and Italian data. However, it can be ${ }_{653}$ seen from Fig: 3, that the Canadian insurance companies didn't face the economic 654 bust at its worst. But, however, being a part of the global financial ecosystem, they 655 are also not completely immune from the crisis. As can be seen from Fig: 3, their ${ }_{656}$ profits moderately slowed down during 2008-2010 and then started to get its normal 657 pace from 2011 onwards.

Moreover, from Fig: 2 and Fig: 3, we can see that the slopes of the accumulated 659 profit curves are steeper for US and German data than that of the Canadian and 660 Italian ones. This implies that the profits of the commercial insurance companies 661 are increasing more rapidly in USA and Germany as compared to Canada and Italy. ${ }_{662}$ Apart from the actual observations demonstrated in Fig: 2 and Fig: 3, these trends 663 are also clearly visible in the forecasted series. Fig: 4 and Fig: 5 represent the 664 ARIMA and ARIMA-GARCH forecasted accumulated profit (as well as the actual 665 profit) for US data over the period 2008-2025. Both the figures show exponential 666 growth of accumulated profit of US commercial insurance companies starting from 667 2011. The same holds true for German data as well. Fig: 7 and Fig: 8 depict the 668 actual and forecasted values of accumulated profit for German for-profit insurance 669 companies. Both the actual and forecasted series speak for the accumulated profits to 670 increase at an increasing rate starting right after the global financial crisis. Unlike the 671 US and German data, Canadian and Italian data portray slightly different pictures. 672 Although, the actual and forecasted profits are growing for these two countries also 673 (as can be seen from Fig: 6 for Canadian data and Fig: 9 and 10 for Italian data), 674 they are only doing so at a decreasing pace. Thus far from the analysis, we have seen 675 some structural differences amongst the profit trends of the insurance companies of 676 the countries under investigation. For US and German data, insurance companies' 677 accumulated profits are increasing at an increasing rate while for Canadian and 678 


\section{Limitations and Future Work}

In our current study, we have conducted empirical analysis of only 04 (four) OECD 681 countries, namely USA, Canada, Germany and Italy. Choice of countries is mostly ${ }_{682}$ driven by the availability of the insurance data at the country level and the scope ${ }_{683}$ of the current study, i.e., incorporating more and more countries in the analysis 684 would out-scope the current investigation in terms of volume. In fact, there is a 685 whole host of other countries where similar studies can be conducted to measure the 686 profit accumulated by the commercial for-profit insurance companies and its future 687 trend. Moreover, the countries chosen in the analysis are all from the same economic 688 basket, i.e., all of them are developed ones. The nature of the profit gathered by ${ }_{689}$ the commercial insurance companies in developing and least developed countries may 690 behave differently than that of the developed ones. Thus the study can be reasonably 691 expanded to include more countries from different economic buckets to get a complete ${ }_{692}$ picture of the accumulated profits made by the commercial insurance companies 693 throughout the world. Moreover, here, we assume the insurance companies' profits 694 are invested in risk free rate, i.e., the insurance companies are assumed to invest 695 their extra premiums in government treasury bills and bonds. But, in practice, they 696 often go for riskier investment to earn more profit. However, as the risk and return 697 always accompany each other, they also have to maintain provisions for the probable 698 losses and may often use these provisions to write off non-performing investments. ${ }_{699}$ As provisions are born out of the retained earnings of the insurance companies, they 700 incur losses on the process. So, to get a more realistic snap of the whole scenario, we 701 should take into account the real investments made by the insurance companies, their 702 actual return on investment and provisions built and used in the process. Avoiding all 703 these company-specific complexities, what we have done here, represents the lower 704 or risk free bound of the profits gathered by the commercial for-profit insurance 705 companies over the years in the country level. Thus this study can be considered as 706 an indicative one of what is going on inside the insurance industries.

\section{Conclusion}

Here, we have discussed several cost heads that are exclusively related to the operation 709 and management of the commercial for-profit insurance companies. For example, 710 commercial insurances are subject to costs like agency commission, advertising and 711 
publicity cost, dividend expenditure and corporate tax on profits earned and premiums 712 collected due to their very nature of business whereas social insurances are gently 713 shielded away from all these cost heads again due to their distinctive nature of 714 operations and method of incorporations. For four OECD countries, namely USA, 715 Canada, Germany and Italy, here we have empirically shown that the premiums 716 collected by the commercial life and non-life insurance companies in these jurisdictions 717 are substantially larger than the corresponding claim settlement and operating expenditides. If the insurance schemes in these regions were implemented in a rather social manner 719 then these extra premiums would have resulted into a huge amount of savings 720 from the policy holders' perspective. These savings along with the opportunity 721 cost there on actually represent the total amount of extra money that the policy 722 holders have so far paid for in order to get insurance coverage. These additional 723 costs could have been easily eliminated if the insurance schemes in these regions 724 were implemented using a government sponsored, compulsory, not-for-profit social 725 insurance program in place of conventional, commercial, for-profit insurance schemes. 726 Here, we discuss the prospect of social insurance in commercial setup like fire, marine, 727 motor, travel, burglary, house insurances and so on alongside its existing role of 728 funding universal health coverage, illness and disability insurance, unemployment 729 and accident insurance scheme and various other social security measures. With 730 the same amount of premiums being collected, social insurance scheme is supposed 731 to perform better than its conventional commercial peers and unlike commercial 732 for-profit insurances, social insurance scheme retains profits in a trust fund after 733 adjusting an equivalent amount of claims and meeting up the same amount of ${ }_{734}$ operating expenditures. These retained profit can then further be used to subsidize 735 future premiums imposed upon the policy holders that would lessen the premium 736 burden upon them.

\section{Declaration}

- Funding: No funding is received to accomplish this work.

- Conflict of Interest: No conflict of interest exists.

- Availability of data and material: The data that support the findings of this 741 study are openly available in OECD Insurance Database at https://www . 742 oecd.org/daf/fin/insurance/oecdinsurancestatistics.htm. 


\section{References}

[1] Actuarial Standards Board (1998). Social Insurance. Actuarial Standard of 746 Practice No. 32 (Doc. No. 062). January 1998.

[2] AHIP.org (2020). Taxes, Fees and Your Premiums. Accessed on April 24, 2020. 748 https://www .ahip.org/taxes-fees-and-your-premiums/ $\quad 749$

[3] Akhigbe, A, Martin, AD and Whyte, AM (2005). Contagion effects of the world's 750 largest bankruptcy: the case of WorldCom, The Quarterly Review of Economics 751 and Finance, 45(2005), 48-64.

[4] Alestalo, M and Uusitalo, H (1987). Growth to limits: the Western European 753 welfare states since World War II, Edited by Flora, Peter, J. Walter de Gruyter. ${ }^{754}$

[5] Anzovin, S (2000). Famous First Facts. item no: 2422, H. W. Wilson Company, 755 ISBN 0-8242-0958-3 p. 121

[6] Chen, R and Wong, KA (2004). The Determinants of Financial Health of Asian 757 Insurance Companies, The Journal of Risk and Insurance, Vol. 71, No. 3, 469-499. 758

[7] DeAngelo, H, DeAngelo, L and Gilson, SC (1994). The collapse of First 759 Executive Corporation junk bonds, adverse publicity, and the 'run on the bank' 760 phenomenon, Journal of Financial Economics, Volume 36, Issue 3, December 761 1994, Pages 287-336.

[8] Dividend.com (2020). Best Life Insurance Dividend Stocks. Accessed on 763 April 24, 2020. https://www.dividend.com/dividend-stocks/financial/ 764 life-insurance/\#tm=3-industry-stocks\&r=ES\%3A\%3ADividendStock $\% 3 \mathrm{~A} \% \quad 765$ 3AStock\%23FG--NYSE\&f_2=life-insurance\&only=meta $\% 2$ Cdata $\% 2$ Cthead $\quad 766$

[9] Duhaime's Law Dictionary (2020), Lex Rhodia: The Ancient 767 Ancestor of Maritime Law - 800 BC, Accessed on April 25, 768 2020, URL:http://www.duhaime.org/LawMuseum/LawArticle-383/ 769 Lex-Rhodia-The-Ancient-Ancestor-of-Maritime-Law--800-BC .aspx. $\quad 770$

[10] Employee Retirement Income Security Act (ERISA) 1974 (USA) 771

[11] Encyclopaedia Britannica (2020). Historical Development Of Insurance. 772 Accessed on April 25, 2020. URL:https://www.britannica.com/topic/ 773 insurance/Historical-development-of-insurance 
[12] Epstein SA (1991). Wage Labor and Guilds in Medieval Europe, University of 775 North Carolina Press, 1991, pp 10-49.

[13] Evang, Karl (1970). Healthcare services in Norway, Oslo, Norwegian Joint 777 Committee on International Social Policy. 778

[14] Feldstein, M. (2005). Rethinking social insurance. American Economic Review, 779 $95(1), 1-24$.

[15] Flower, HI. (ed.) (2004) Cambridge Companion to the Roman Republic, 781 Cambridge University Press, ISBN-10: 0521003903. 782

[16] Gannik, DHE, Wagner, M (1976). Primary health care. The national healthcare 783 system in Denmark. Bethesda: National Institutes of health. pp. 43-44. 784 hdl:2027/pur1.32754081249264.

[17] Gilbert and Rivington (1854). Amicable Society, The charters, acts of 786 Parliament, and by-laws of the corporation of the Amicable Society for a 787 perpetual assurance office, 1854, p. 4

[18] Gopffarth, D. and Henke, K. D. (2013). The German central health fund-recent 789 developments in health care financing in Germany. Health Policy, 109(3), 246-252. 790

[19] Grigg, J (1978). Lloyd George, The People's Champion, 1902-1911 (1978). 791

[20] International Monetary Fund (2020), International Financial Statistics, 792 Accessed on August 21, 2020. https://data.imf.org/regular.aspx?key= 793 61545867

[21] Jovinelly, Joann and Netelkos, Jason (2006). The Crafts And Culture of a 795 Medieval Guild. Rosen Central, ISBN 9781404207578.

[22] Kuhnle, S; Hort, SEO. (2004). The developmental welfare state in Scandinavia: 797 lessons to the developing world. Geneva: United Nations Research Institute for 798 Social Development. p. 7.

[23] Lammam, C., Palacios, M., \& Clemens, J. (2013). RRSPs and an Expanded 800 Canada Pension Plan. Fraser Institute Studies in Economic Prosperity.

[24] Life Ant (2020). Life Insurance Commissions - How Life Insurance 802 Agents Are Paid. Accessed March 23, 2020. https://www.lifeant.com/ 803 life-insurance-commissions-how-life-insurance-agents-are-paid/. 
[25] McDonald, R and Paulson, A. (2015). AIG in Hindsight. Journal of Economic 805 Perspectives-Volume 29, Number 2-Spring 2015-Pages 81-106.

[26] Marcus, GJ (1975). Heart of Oak: A Survey of British Sea Power in the Georgian 807 Era. Oxford University Press. p. 192. ISBN $0192158120 \quad 808$

[27] Nelli, HO (1972). The Earliest Insurance Contract: A New Discovery. The 809 Journal of Risk and Insurance, Vol. 39, No. 2 (Jun., 1972), pp. 215-220. 810

[28] OECD (2020A). OECD Insurance Database, Accessed on April 27, 2020. URL: 811 https://stats.oecd.org/Index.aspx?DatasetCode=INSIND 812

[29] OECD (2020B). OECD Insurance Database. Balance Sheet and Income: 813 Commissions in the reporting country (Direct, Life). Retrieved from: https: 814 //stats.oecd.org/Index.aspx?DatasetCode=INSIND 815

[30] OECD (2020C). OECD Insurance Database. Balance Sheet and Income: 816 Commissions in the reporting country (Direct, Non-Life). Retrieved from: https : 817 //stats.oecd.org/Index.aspx?DatasetCode=INSIND 818

[31] Palmer, S (2007). Edward Lloyd, Oxford Dictionary of National Biography. DOI: 819 doi:10.1093/ref : odnb/16829

[32] Pinches, GE and Trieschmann, JS (1974). Journal of Risk and Insurance, Vol. 821 41, No. 4 (Dec., 1974), pp. 563-577.

[33] Serner, Uncas (1980). Swedish health legislation: milestones in reorganisation 823 since 1945. In Heidenheimer, Arnold J.; Elvander, Nils; Hulten, Charly (eds.). 824 The shaping of the Swedish healthcare system. New York: St. Martin's Press. p. 825 103. ISBN 978-0-312-71627-1.

[34] Shah, SS and Trice, C (2020). Progressive's big 2017 ad spend 827 bump coincides with strong premium growth. Accessed on April 24, 828 2020. https://www.spglobal.com/marketintelligence/en/news-insights/ 829 latest-news-headlines/44021562

[35] Sikes, SA (2014). The turn-of-the-year effect and tax-loss-selling by institutional 831 investors, Journal of Accounting and Economics, 57(2014), 22-42.

832

[36] Tyagi, A. (2017). Effects Of Global Financial Crisis On Global Economy. $8 з 3$ Deliberative Research, 35(1), 57-61. 
[37] US Insurance Agents (2020). How Much Do Insurance Agents 835 Make. Accessed March 23, 2020. https://usinsuranceagents.com/ 836 how-much-do-insurance-agents-make/ 837

[38] U.S. Bureau of Labor Statistics (2020). Insurance Sales Agents - 838 Summary. Accessed March 23, 2020. https://www.bls.gov/ooh/sales/ 839 insurance-sales-agents . htm\#tab-1

[39] Vaughan, E. J. (1997). Risk Management. New York: John Wiley. ISBN-10: 84 047110759X

[40] Vicarelli, G. (2019). The Creation of the NHS in Italy (1961-1978). Dynamis: 843 Acta Hispanica ad Medicinae Scientiarumque Historiam Illustrandam, 39(1), 21- 844 43.

[41] Whitman, K. (2008). An Overview of the Railroad Retirement Program. Soc. ${ }_{846}$ Sec. Bull., 68, 41. 